\title{
Quando a Velha República era Nova...*
}

\author{
Cândido Motta Filho \\ Professor Emérito da Faculdade de Direito da \\ Universidade de São Paulo.
}

Quando a velha República era nova, tudo era novidade como agora, em nossos dias. As dificuldades, muitas e graves, dificuldades de tôda espécie - econômicas, financeiras, religiosas, militares, políticas - eram transpostas com espírito de luta.

O sonho impresso no Manifesto Republicano de 1870 surgiu como um compromisso aceito, como um estímulo e como uma afirmativa de convições.

A conviç̧ão vinha de longe, transmitida por muitas gerações, o estímulo era para a luta de um momento histórico em que, diante das desilusões da monarquia, se movimentava o inconformismo da mocidade acadêmica, aquela que se reunia nas academias de direito, de engenharia e nas academias militares.

Depois, envelheceu mais depressa do que se esperava, muito embora êsse envelhecimento seja fàcilmente explicado nos países novos.

O regime, fundado com desassombro e com entusiasmo, não alcançou os sessenta anos. Quando, em 1930, recebeu

*. Discurso lido pelo professor emérito Ernesto Leme, como representante do autor, na sessão comemorativa do centenário do manifesto republicano de 1870 , realizada a 3 de dezembro de 1970 , no salão nobre desta Faculdade. 
atestado de morte, que aparecia na ponta das armas de uma revolução vitoriosa, - já tinha morrido ou, pelo menos, estava morre não morre. .

Em outubro de 1930, a resistência pessoal do Presidente Washington Luis, com seu pequeno revólver em punho e alguns companheiros, era a resistência de um homem, de grande bravura pessoal, mas não era de um regime.

Em tôrno do Presidente Washington Luis tudo parecia certo e tôda lealdade induvidosa. Mas, na verdade, tudo aparecia como errado e tôda deslealdade justificada. Havia, nos possíveis êrros do govêrno, a mão vacilante de uma república deprimida por uma velhice precoce.

O sinal dessa velhice não foi bem percebido no momento. Nem mesmo para muitos que se opunham ao govêrno. Ninguém poderia atinar que o bacharel Rui Barbosa, quando divergia do coronel Pinheiro Machado, que comandava as hostes governamentais, no posto de general, que lhe fôra dado pelo Marechal Floriano Peixoto, estava pondo à mostra as insuficiências circulatórias da República!

É verdade que, ambos, eram bacharéis. Mas Rui Barbosa era um bacharel autêntico, um político com o espírito formado nas aspirações dos grandes centros de cultura; ao passo que Pinheiro Machado, residindo no morro da Graça, no Rio, -- apesar de ter passado pela Faculdade de Direito de São Paulo, era um homem do interior, uma expressão nacional do coronelismo, que se fazia poder em todos os municípios e recantos do Brasil.

Num país, de cultura política de caráter epidérmico, onde a çonquista do poder e seu exercício se faziam sob o império das circunstâncias, a ordem civil era concertada no diálogo entre os bacharéis da cidade e os coronéis do interior.

Enquanto permaneceu a economia agrária, enquanto os interêsses nacionais se vinculavam aos interêsses dos fazendeiros, o diálogo é que pacificava o país, com uma ordem jurídica capaz de assegurar um mínimo de violência, numa tranqüilidade, mais ou menos generalizada. 
O paternalismo monárquico também desapareceu assim. Houve também um momento em que a monarquia envelheceu. E tudo foi por água abaixo!...

O Imperador ficou sòzinho em campo, uma vez que os partidos políticos existentes não passavam de "vinho da mesma pipa". O sistema de circulação política propiciado pelos bacharéis e coronéis, deixara de funcionar .

Isso aconteceu ao aproximar-se de 1870. Para Oliveira Viana, foi mesmo, nessa data, que a moléstia mortal tomara conta da monarquia constitucional e representativa.

Dando as razões porque se fixava nessa data, êle sustenta que as encontrou num pequeno período que vai da queda do gabinete de Zacarias ao Manifesto Republicano de 1870.

Assim, nesse espaço de tempo, a monarquia começou a morrer. $O$ poder pessoal do Imperador, tão rudemente atacado, era a última tentativa feita para salvar a monarquia. O sistema parlamentar já não existia. Oliveira Viana narra o acontecido: - "Logicamente, dada a situação unânimemente liberal da Câmara, demitido Zacarias, caberia a outro procer liberal organizar o novo Gabinete. Entretanto, o Imperador chamou Itaboraí - e o novo Gabinete, que apareceu deante da Câmara, - demitido Zacarias, caberia a um outro procer liberal, organizar o novo Gabinete, que apareceu, deante da Câmara unânimemente liberal, era unânimemente conservador" ( $O$ ocaso do Império, pg. 23).

O Manifesto Republicano foi, por isso tudo, pelo seu calor estimulante, um toque de reunir. Os clubes radicais transformaram-se em clubes republicanos. Os soldados que voltavam da guerra eram saudados como portadores de novas esperanças sociais e políticas.

O primeiro resultado concreto do Manifesto de 70 é a organização, sob base de disciplína do Partido Republicano de São Paulo, com a convenção de 1873 , e na capital da província. 
Entre muitos os monarquistas contudo e, mesmo no próprio Imperador havia a consciência de um perecimento.

Viveiro de Castro dá o seu testemunho: - "Lembrome de ter assistido, ainda muito menino, Satyro Faria pronunciar uma conferência, “cujo diapasão dará uma compléta idéia, o seguinte trecho: - “o edifício social ameaça ruina: - ha saúva nos alicerces!" (Contribuição à biografia de D. Pedro $I I)$.

Muito mais tarde, Euclídes da Cunha, em seu ensáio Da Independência à República fala num "regime teóricamente extinto e implicativo de novas transformações sociais".

O Manifesto Republicano, do qual nasce, em 1873, o Partido Republicano, aproveitara de um artigo editorial de Francisco Otaviano e Joaquim Manuel de Macedo e outros que dirigiam o Diário do Povo. E transcreve o seguinte trecho: - "São gravíssimas as circunstâncias do país. No exterior arrasta-se uma guerra desastrada. No interior um espectáculo miserando. Fórmulas aparentes de um govêrno livre, última homenagem que a hipocrisia rende ainda à opinião do século: - grandes instituições políticas anuladas e a sua ordem constitucional substituida por um arbitrio disfarçado."

A multiplicação de dificuldades, - a questão abolicionista, a questão religiosa, a questão militar; o fato de ter o Minístro Ouro Preto de ouvir, na Câmara, o padre João Manuel bradar "Viva a República!"; o episódio do Imperador ouvi as queixas do Marques de São Vicente para dizer que se o povo quisesse a República êle iria ser professor; a maneira pela qual Benjamin Constant recebe os oficiais chilenos do navio-escola "Almirante Cochrane" tudo isso mostrava que a monarquia estava por um fio. Como diz José Maria Belo, — “à abolição em 1888 levára consigo o derradeiro sentido histórico do Império, de que a festa noturna aos chilenos na Ilha Fiscal é como o último fogo de artifício. 
Acrescente-se 15 de novembro, data em que os fatos por mais contraditórios que sejam, - com o comportamento de Deodoro, com a atitude esquiva de Floriano em frente ao Visconde Ouro Preto, com a atividade dos chefes republicanos, entre êles Quintino Bocaiúva, Francisco Glicério e Aristides Lobo, - explicam a frase de Aristides Lobo: - "O povo assistiu, atônito, surpreso, sem conhecer o que significava um dos principais corresponsaveis daquêle acontecimento. Muitos acreditavam sinceramente estar vendo uma parada. Era um fenomeno digno de ver-se".

Raul Pompeia, guardou, em seu mundo emocional, o que seus olhos curiosos viram, quando da partida da familia real para o exílio, deante de uma cidade tranqüila e de um céu tranqüilo.

Mas, apezar disso, não foi fácil a implantação da república federativa. A construção de uma nova ordem institucional é dramàticamente difícil. Ela provocou naturalmente divergências e contradições, que se fizeram sentir no seio da Constituinte de 1891, com um ante-projeto de Constituição, redigido pelo Conselheiro Rui Barbosa. Ésse ante-projeto resultara de três outros de uma comissão nomeada pelo Govêrno Privisório, no qual se fixou a autonomia originária dos Estados membros compondo a União soberana.

Na sessão de 16 de dezembro de 1890, Rui Barbosa, então Minístro da Fazenda, proclama que a Constituinte era a mais urgente das medidas financeiras e procura enfrentar a influência dos exaltados, dizendo: - "Grassa por ai, senhores, um apetite desordenado e doentio de federalismo, cuja expansão sem corretivo seria a perversão e a ruina da reforma federal."

A República encontrava o país carregado de compromissos, aos quais se somava a carga de desconfianças geradas pela revolução. Os três poderes começam a funcionar por entre desentendimentos. Diante da atitude do Legislativo, Deodoro resolve dissolvê-lo e, depois, amargurado e 
doente, deixa a Presidência da República. O govêrno de Floriano Peixoto é obrigado, em 1892, a enfrentar uma situação revolucionária.

Consegue, afinal, a República, um período de progresso e de relativa tranqüilidade, depois de ter dado motivo ao exílio de Rui Barbosa e a luta, sem tréguas, contra os adversários de Floriano, cuja atitude despertara, em torno dêle, uma aura de fanatismo.

Com Prudente de Morais, vem a anistia e, com ela, um céu mais tranqüilo após nove anos de tormenta. A campanha de Canudos, colocada politicamente em seus devidos termos, não impede que a exaltação jacobinista arme o braço do assassino do Marechal Bittencourt, veterano da guerra do Paraguai, que assumira o Ministerio da Guerra.

O govêrno Campos Sales, com a política dos governadores, é o da reconstrução financeira, com a orientação deflacionista de Joaquim Murtinho. O de Rodrigues Alves é de orientação progressista, reclamando a votação do Codigo Civil, em nome da ordem jurídica, ampliando a política de penetração ferroviária e a transformação urbanística e sanitária da Capital Federal.

Mas, em meio a êsse progresso, que afastou o terrorismo da febre amarela, a tranqüilidade começou a ser desfeita. - Para repelir a deterioração política, o presidente Afonso Pena não só percorre o país de norte ao sul, como tenta implantar uma nova política na qual a atividade do Estado se apresentaria sempre que a atividade privada se mostrasse incapaz.

O Estado liberal, não intervencionista estava sendo chamado para intervir. O convênio de Taubaté, tentando a valorização cafeeira e a reforma tarifária, robustecendo a vida financeira delineava, realmente, um novo rumo, com apoio de homens cultos, como David Campista e Carlos Peixoto.

Quando se movimentavam os partidários da candidatura do Marechal Hermes para suceder Afonso Pena, em 
contraposição, se vislumbrava uma tendência oficial para libertar o país dos costumes políticos que Pinheiro Machado se utilizava como fazedor de reis.

Ao empossar-se na Presidência da Câmara dos Deputados Federais, Carlos Peixoto procurou fazer sentir que se chegava a uma época de renovação. E ela deveria ser conduzida pela eleição de David Campista. Mas o que aconteceu foi a resistência da política imperante e, conseqüentemente, a debandada geral. A candidatura Hermes venceu, em marcha batida, apesar da campanha civilista de Rui Barbosa que prometia a renovação com o apôio dos governos da Bahia e de São Paulo e do Estado do Rio.

O sossôbro da tentativa de renovação, as pressões e os desenganos que recebeu e principalmente a morte de um filho, levaram Afonso Pena ao túmulo em 14 de junho de 1909.

A campanha de Rui denunciou ostensivamente o fim do diálogo entre os coronéis e bacharéis. $\mathrm{O}$ vencedor $\mathrm{Pi}$ nheiro Machado, o chantecler dos escuros da República, tornou-se uma figura marcada como o responsável pela falsificação democrática em que o país vivia.

$O$ Govêrno Hermes, que enfrentou a revolta da esquadra, os acontecimentos provocados pelos fanáticos sertanejos da região do Contestado, entre Santa Catarina e Paraná, aumentavam a desconfiança contra a chefia de Pinheiro Machado. Quando seu nome foi lembrado para Presidente da República, êle próprio sentiu que o seu prestígio estava abalado. Foi quando Venceslau Brás se elegeu à Presidência para o quatriênio de 1914-1918.

A situação do Brasil em frente à guerra mundial foi uma preocupação imposta ao govêrno da República, que facilitou a êle descartar-se da influência de Pinheiro Machado.

Geralmente, as guerras trazem consigo uma dose de fermento revolucionário. A guerra de 1914, por ser uma guerra mundial, trazia consigo fermentos revolucionários que atingiam quase todos os povos livres. 
Findo o govêrno Venceslau Brás, dentro dessa enorme preocupação, lembrou-se o nome do Conselheiro Rodrigues Alves para sucedê-lo, uma vez que êle se mostrara com estatura de um estadista nas horas solares do regime. Mas, Rodrigues Alves faleceu, abrindo-se, novamente, o problema da sucessão.

Pinheiro Machado morrera assassinado, depois que um deputado de Pernambuco apresentou à Câmara dos Deputados, numa brincadeira de mau gosto, projeto que se resumia num único artigo: - "Elimine-se o general Pinheiro Machado".

Rui Barbosa, que era amigo e adversário de Pinheiro Machado sentiu-se profundamente abalado com essa morte, que, afinal, desfazia, o quadro em que êle vivia.

Antonio Joaquim da Costa, que viveu na intimidade de Rui, em seu depoimento sôbre o acontecido, descreve Rui nervoso e trêmulo, com as faces úmidas, onde corriam as lágrimas.

O govêrno Epitácio Pessôa procura um novo equilíbrio e não o encontra. Vive numa fase politica tipicamente revolucionária. Enquanto já não mais se repele o intervencionismo do Estado, que vai em socorro do café, cresce, em forma agressiva, a oposição ao govêrno.

Em 5 de julho de 1922, noticiava-se o levante de protesto contra a prisão do Marechal Hermes da Fonsêca. O episódio do forte de Copacabana foi uma vitória dos vencidos, num fracasso revolucionário.

Em 1922, reuniu-se, em São Paulo, a Semana de Arte Moderna, na qual, pela repulsa ao convencionalismo da mediocridade artística existente, se fazia sentir, no plano da cultura, o aparecimento de uma consciência revolucionária.

Depois da Semana de Arte Moderna, segue-se, entre escritores e jornalistas, um período de procura, de crítica e de projetos de renovação política. Enquanto o Presidente Washington Luis tenta enfrentar a maior crise do café, 
juntam-se os intelectuais num esfôrço para enfrentar os problemas fundamentais do Brasil.

Paulo Prado, um dos responsáveis pela Semana de Arte Moderna, não só anima os jovens, como, êle próprio ingressa no movimento da redescoberta do Brasil, partindo, como queria Oswald de Andrade, do marco zéro.

Paulo Prado, que vinha da aristocracia cafeeira de São Paulo, escreve, em 1925, Paulistica, onde se lê esta desalentadora denúncia política, destinada a pôr em brios a mocidade revolucionária: - "Tôda a história política de São Paulo, a partir do nefasto século XVIII de capitania independente, é um lamentável quadro do que é a decadência da liberdade nos povos tranquilos, humildes e respeitosos. Terra da unanimidade, exclamou Martim Francisco, num assomo de indignação andradina."

"Unanimidade e adesismo - tem sido ha mais de um século o traço saliente do sentimento politico paulista, para quem o estuda como um fenomeno histórico, de raizes fundas e misteriósas. Desde a independência, a opinião pública de São Paulo, ou o que melhor nome tenha, - corre pressurosa atrás do vencedor, que ela despresava momentos antes da vitoria." E termina as páginas preambulares com estas palavras: - "Já se disse que uma nação é um plebicito continuado dia a dia. Sem o amor às coisas publicas, os agrupamentos gregários de milhões de cabeças, não possuem a vontade de convivência e coesão, que são os carateres fundamentais do estado nacional."

Entre 1926 e 1928, escreve o Retrato do Brasil, onde repete a acusação, depois de mostrar o mundo entregue a uma revolução: - "Em meio dêsse cataclismo em preparo, que papél caberá ao Brasil? O da mais completa ignorância do que se passa pelo mundo a fóra. Dorme o sono colonial. Ainda acredita no embalo dos discursadores, na teoria dos doutrinários e na enganadora segurança dos que monopolisaram, pela fraquesa dos indecisos, as posições de domínio e de proveito." 
Ao lado de Paulo Prado está Graça Aranha. O autor de Canaan sustenta que o movimento modernista devia ser um movimento de renovação radical dos valores políticos. Em seu romance $A$ viajem maravilhosa, a revolução, com todos os seus contornos, aparece como uma esperança.

Um dos personagens do romance segue o mesmo raciocínio de Paulo Prado, ao descrever os quadros políticos do país e o comportamento de suas elites: - "O que predomina, diz êle, é a ausência de responsabilidade. Ninguém se julga responsável diante de si mesmo ou da opinião pública. Daí, uma absoluta ausência de escrupulos, a conquista do dinheiro, das posições, de govêrno."

Graça Aranha, cujo inconformismo nascera quando ainda estudante, no Recife, viu agravar-se a situação da república no govêrno Epitácio Pessôa. O governo Bernardes era a República perdendo suas últimas resistências. Chegou a conspirar e foi preso porque êle via que se multiplicavam osl casos políticos com soluções inúteis, ¡além de movimentos revolucionários como o que eclodira em São Paulo, em 1924, e como a revolta do couraçado São Paulo, A coluna Prestes, da qual faziam parte os revolucionários de São Paulo, cortava, de cá pra lá, o sertão brasileiro.

O próprio govêrno Bernardes começou a perceber que havia algo de errado na estrutura constitucional do país, que punha em dúvida a autoridade constituída. Por isso, promoveu, em 1926, a reforma constitucional, reforçando o poder federal e procurando, como disse o deputado Herculano de Freitas na Câmara, por têrmo no conflito entre os poderes.

Ao aproximar-se de 1930, podia-se verificar, sem maiores esforços, que a juventude estudiosa, voltava-se para os problemas do Brasil, de sua geografia, de seu processo populacional, de seu comportamento social e político. Os livros prediletos eram, por êsse tempo, além de Paulo Prado e Graça Aranha, os de Alberto Torres, de Capistrano de Abreu, de Tavares Bastos, de Teodoro Sampaio e de tantos outros. As correntes ideológicas já tinham transposto 
as fronteiras do país. Sob a inspiração de Graça Aranha, saía, em 1928, sob a direção de Renato de Almeida, a revista Movimento Brasileiro, que se consagrava inteiramente aos novos temas.

Depois das dissenções em tôrno das candidaturas de Júlio Prestes e de Getúlio Vargas, "a revolução contra o govêrno Washington Luís preparava-se abertamente em todo pais. Quando em outubro a revolução eclodiu, Graça Aranha, emocionadíssimo, sofre seu primeiro ataque de angina de peito e sob essa emoção chega a escrever o Canto do revolucionário.

O Manifesto Republicano de 1870 não podia ser mais escutado, numa época em que, ao lado do comunismo e do fascismo, novas fôrças sociais conquistavam a vida política de todos os povos cultos. Em 1919, como paranínfo da turma dêsse ano, Herculano de Freitas, figura de pról do Partido Republicano, avisava aos moços: — "Facilmente se reconhece que a sociedade está atacada de dois generos contrários de loucura coletiva: - A loucura da riqueza pelos negócios; a loucura da destruição pela anarquia."

Tudo aquilo que se dizia e se fazia na velha República, quando ela era nova, emudecera, para se ouvir o clamor das reivindicações e dos protestos, os gritos de guerra e de revolta, enfim, os tormentos do nascimento de uma nova era.

A velha República fizera o seu papel. Morria a olhos vistos, num palco onde ela não podia mais respirar. $O$ pano de boca descia e o público deixava o teatro sem bater palmas, porque suas mãos se preparavam para novas lutas. 